\title{
Testing of pH Range for the Better Growth and Sporulation of $B$. theobromae
}

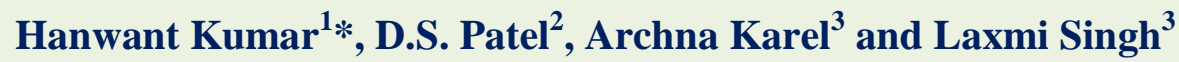 \\ ${ }^{1}$ Department of Plant Pathology, Agriculture University, Jodhpur, India \\ ${ }^{2}$ Plant Pathology, C.P. College of Agriculture, SDAU, Sardarkrushinagar, India \\ ${ }^{3}$ Food \& Nutrition, Agriculture University, Jodhpur
}

*Corresponding author

\section{A B S T R A C T}

\section{Keywords}

Rose, Die-back, $\mathrm{pH}$, Sporulation, Growth

Article Info

Accepted:

10 June 2018

Available Online:

10 July 2018
Rose is one of the important floricultural crops and is universally acclaimed as the 'Queen of flowers'. It is principle cut flower and growing more or less in all parts of north Gujarat. Therefore solving the problem associated with rose cultivation is necessary to increase the productivity. Die-back is a serious malady of rose causing considerable economic losses and a threat to rose cultivation in the area. The present investigations indicated that fungus could grow under wide range of $\mathrm{pH}$ from 4.5 to 9.0. However $\mathrm{pH} 6.5$ and 6.0 proved to be optimum for the growth and sporulation of the fungus. More information on this problem for devising suitable control measures for preventing crop losses.

\section{Introduction}

Rose (Rosa spp., Family: Rosaceae) is one of the nature's beautiful creations and is universally acclaimed as "Queen of flowers". No other flower is a better symbol of love, adoration, innocence and other virtues than the rose and not in our time only but so it has been for thousands of years (Fairbrother, 1965; Gaulf and Synge, 1971).

Rose has become the part and parcel of life, being connected with all phases of life right from birth to death. A large quantity of rose flowers is used for decorative purpose.
Besides it is used for making essence, rose water for flavouring sweets and other food articles as well as sprinkle for welcoming guests on festive occasions. Hips of some rose species are rich in vitamin $\mathrm{C}$ while its petals are used for preparing Gulkand and Pankhuritwo food articles of delicacy (Dhua, 1999).

Rose is affected by several fungal, bacterial, and viral diseases. The important fungal diseases are Die-back Diplodia rosarum (Srivastava, 1961), Powdery mildew Spherotheca pannosa var. rosae (Wallr.) Lev. (Pal, 1972), Rust Phragmidium butleri syd. (Chakravarti et al., 1969), Botrytis bud and 
twig blight Botrytis cinerea (Pers.) Fries (Chohan and Kour, 1976), black leaf spot Diplocarpon rosae (Walf.) (Bardoloi and Ganguli, 1963) and leaf blight Alternaria alternata (Rao, 1964).

Among all the fungal diseases, die- back in one of the serious disease throughout the country caused by Botryodiplodia theobromae (Pat.) Colletotrichum gloeosporioides (Penz.), Fusarium solani (Mart.) Sacc. and Diplodia rosarum (Pal, 1972; Vir and Sharma 1985; Shukla and Choudhury, 1991; Dhua, 1991; Malik and Dadlani, 1984).

\section{Materials and Methods}

For studying the effect of $\mathrm{pH}$ on the growth and sporulation of pathogen, Richard's medium was adjusted to $\mathrm{pH} 4.5,5.0,5.5,6.0$, $6.5,7.0,7.5,8.0,8.5$ and 9.0 in liquid state by using $0.1 \mathrm{~N} \mathrm{HCl}$ and $0.1 \mathrm{~N} \mathrm{NaOH}$ solutions with the help of Beckman's pH meter. The $\mathrm{pH}$ was adjusted before sterilizing and adding agar in case of solid media. Solid and liquid media in Petri plates and flasks were inoculated with $4 \mathrm{~mm}$ diameter dished of 15 days old pure culture of $B$. theobromae was incubated at room temperature $\left(27^{\circ} \pm 2^{\circ} \mathrm{C}\right)$.

The observations for linier growth were recorded at every 24 hours interval in solid media while, dry mycelial weight, sporulation and $\mathrm{pH}$ were recorded after 15 days of inoculation both in solid and in liquid media. In solid media, dry mycelial weight was obtained by melting the inoculated petri dishes of all treatments after 15 days of inoculation. Then the mycelia mat from the melted media taken out with the help of forceps and put in between two previously weighted Whitman's filter paper No. 42. Then after in both the cases mycelial mats were washed with hot water to remove adhering media. Mycelia mat with filter paper were oven dried at $60^{\circ} \mathrm{C}$ till constant weight and cooled at room temperature before weighing. The dry weight was measured on monopan balance.

\section{Results and Discussion}

Richard's medium with and without agar was selected as a basal medium in the study. In solid media linear growth, spore count.

The results revealed that the fungus could grow in wide $\mathrm{pH}$ range from 4.5 to 9.0. Considering the linear growth, significantly maximum mycelial growth $(90.00 \mathrm{~mm})$ was obtained at $\mathrm{pH} 6.5$ as compared to the rest. The next best was pH 6.0 (84.33) followed by $\mathrm{pH} 7.0$ (82.00). With increase in $\mathrm{pH}$ above 7.0 and decrease below $\mathrm{pH} 5.5$, linear mycelial growth was reduced.

Considering sporulation in solid media, maximum spores per optical field were observed in $\mathrm{pH} 6.5$ which was significantly higher than the rest. The next best in order of merit were $\mathrm{pH}$ 6.0, 7.0, 7.5, and 5.5 in all solid media.

In liquid media, dry mycelial weight, spores per optical field and drift in $\mathrm{pH}$ were recorded. In liquid media maximum dry mycelial weight was yielded in pH 6.0 (1017.33 mg) followed by pH $6.5(1003 \mathrm{mg})$. The next best in order of merit were $\mathrm{pH} 7.0,5.5,7.5$ and 5.0. Considering sporulation in liquid media, maximum spores per optical field were observed in $\mathrm{pH} 6.5$ (35) followed by $\mathrm{pH} 6.0$ (26). The next best were $\mathrm{pH} 5.5,5.0,7.0$ and 7.5 , which were statistically at par with each other. In $\mathrm{pH}$ below 5.0 and in above 8.0 sporulation was not observed.

From the above results (Table 1 and 2), it is observed that neutral to slightly acidic media were proved to be more favourable as compared to alkaline. For the growth and sporulation of B. theobromae optimum $\mathrm{pH} 6.0$ to 6.5 in both solid and liquid media. 
The effect of $\mathrm{pH}$ on the growth and sporulation of $B$. theobromae indicated that the fungus could grow at a wide range of $\mathrm{pH}$ from 4.5 to 9.0 but the optimum $\mathrm{pH}$ laid 6.0 to 6.5 in solid and liquid media. The earlier workers Bhatnagar (1970), Sabalpara (1983), Patel (1971), Patel (1989) and Dambhla (2001) proved that B. theobromae grow well in neutral to acidic medium. Our results are in line with the findings of earlier workers.

Table.1 Growth and Sporulation of B.theobromae at different hydrogen-ion concentration in solid media

\begin{tabular}{|c|c|c|c|}
\hline Sr. No. & Initial pH & Linear growth (mm) & No. of spores/ optical field \\
\hline 1. & 4.5 & 36.00 & $\mathbf{0}$ \\
\hline 2. & 5.0 & 46.33 & 4 \\
\hline 3. & 5.5 & 64.67 & 7 \\
\hline 4. & 6.0 & 84.33 & 17 \\
\hline 5. & 6.5 & 90.00 & 43 \\
\hline 6. & 7.0 & 82.00 & 10 \\
\hline 7. & 7.5 & 64.67 & 8 \\
\hline 8 & 8.0 & 42.67 & 3 \\
\hline 9 & 8.5 & 24.33 & $\mathbf{0}$ \\
\hline 10. & 9.0 & 19.00 & $\mathbf{0}$ \\
\hline \multirow{3}{*}{\multicolumn{2}{|c|}{$\begin{array}{l}\text { S. Em. } \pm \\
\text { C.D.AT } 5 \% \\
\text { C. V. }(\%)\end{array}$}} & 1.12 & 0.66 \\
\hline & & 3.32 & 1.98 \\
\hline & & 3.5 & 12.40 \\
\hline
\end{tabular}

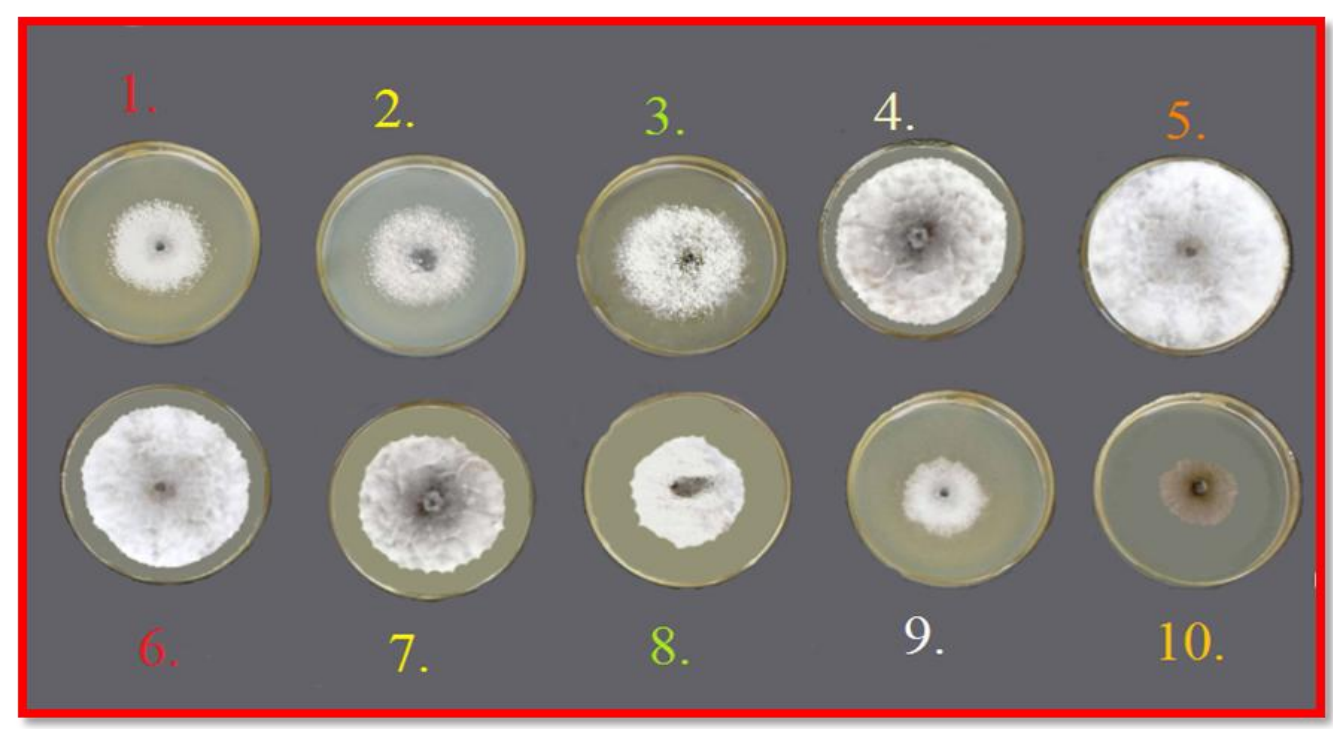

\begin{tabular}{|c|c|c|c|}
\hline Sr. No. & Initial $\mathbf{~ p H}$ & Sr. No. & Initial $\mathbf{~ p H}$ \\
\hline 1. & 4.5 & 6. & $\mathbf{7 . 0}$ \\
\hline $\mathbf{2 .}$ & 5.0 & 7. & $\mathbf{7 . 5}$ \\
\hline 3. & 5.5 & 8. & $\mathbf{8 . 0}$ \\
\hline $\mathbf{4 .}$ & 6.0 & 9. & $\mathbf{8 . 5}$ \\
\hline $\mathbf{5 .}$ & $\mathbf{6 . 5}$ & $\mathbf{1 0 .}$ & $\mathbf{9 . 0}$ \\
\hline
\end{tabular}


Table.2 Dry mycelial weight and sporulation of $B$. theobromae at different hydrogen-ion concentration in liquid media

\begin{tabular}{|c|c|c|c|c|}
\hline Sr. No. & $\begin{array}{c}\text { Initial } \\
\text { pH }\end{array}$ & $\begin{array}{l}\text { Dry mycelial } \\
\text { weight (mg) }\end{array}$ & $\begin{array}{l}\text { No. of spores/ } \\
\text { optical field }\end{array}$ & $\begin{array}{c}\text { Final } \\
\text { pH }\end{array}$ \\
\hline 1. & 4.5 & 455.33 & 0 & 7.5 \\
\hline 2. & 5.0 & 690.00 & 11 & 7.5 \\
\hline 3. & 5.5 & 782.67 & 13 & 8.5 \\
\hline 4. & 6.0 & 1017.33 & 26 & 8.0 \\
\hline 5. & 6.5 & 1003.00 & 35 & 8.0 \\
\hline 6. & 7.0 & 838.67 & 11 & 8.5 \\
\hline 7. & 7.5 & 744.67 & 11 & 8.0 \\
\hline 8 & 8.0 & 628.33 & 3 & 8.0 \\
\hline 9 & 8.5 & 435.00 & 0 & 8.5 \\
\hline 10. & 9.0 & 332.33 & 0 & 8.5 \\
\hline & $\begin{array}{l}\text { S. Em. } \pm \\
\text { C. D. AT } \\
5 \% \\
\text { C. V. }(\%)\end{array}$ & $\begin{array}{c}6.98 \\
20.72 \\
1.74\end{array}$ & $\begin{array}{l}0.49 \\
1.48 \\
7.73\end{array}$ & \\
\hline
\end{tabular}

The studies indicated that fungus could grow under wide range of $\mathrm{pH}$ from 4.5 to 9.0 . However $\mathrm{pH} 6.5$ and 6.0 proved to be optimum for the growth and sporulation of the fungus.

\section{References}

Batnagar, L.G., Studies on Botryodiplodia stem end rot of lime fruit. M. Sc. (Agri) thesis, Univ. of Udaipur, Udaipur (1970).

Bordoloi, D.N. and Ganguli, D., Black spot of rose caused by Diplocarpon rosae Wolf. Indian Phytopath., 16: 255- 259 (1963).

Chakravarti, B.P., Kumar, S. and Kumar, T.B., F. A. O. Plant Prot. Bull. 18: 46 (1969).

Chohan, J.S. and Kaur, S., Grey mold and pestalotiopsis rot of rose buds and flowers. Indian Phytopath., 29: 98 (1976).

Dambhla, D.S., Studies on die-back disease of rose (Rosa hybrida) under south Gujarat condition. M. Sc. (Agri.) Thesis, submitted to Gujarat Agricultural University, Sardarkrushinagar (2001).

Dhua, R.S. (1999). Floriculture and landscaping, Naya Prakash, Calcutta. pp.

Fairbrother, F., Roses. Penguin, Great Britain (1965)

Gaulf, S.M. and Synge, R.M., The dictionary of Roses in colour, Rainbird publication group Ltd. London (1971).

Malik, R.S. and Dadlani, N.K. (1984). Rose cultivation in India. Indian Horticulture. (7-9): 27-28. 
Pal, B.P. (1972). The rose growing in India. I.C.A.R. Publication, New Delhi. pp. 161-165.

Patel, P.B., Investigation on twig blight ( $B$. theobromae) and occurrence of sapota disease in South Gujarat. M.Sc. (Agri.) Thesis, Submitted to Gujarat Agricultural University, Sardarkrushinagar. pp. 63-67 (1989).

Rao, V.R. and Srivastava, D.N., Epidemiology and control of die-back of rose incited by Diplodia roserum Fries. Indian Phytopath. 16: 151- 157 (1963).

Sabalpara, A.N. (1983). Investigations regarding twig blight and die-back disease of mango caused by $B$. theobromae Pat. M.Sc. (Agri.) Thesis, Submitted to Gujarat Agricultural University, Sardarkrushinagar.

Shukla, P. and Chaudhary, P.N. (1991). Fungi associated with die-back of roses. Indian J. Mycol. Pl. Pathol., 21 (2): 213-214.

Srivastava, M.P. and Tondon, R.N., Influence of temperature on Botryodiplodia rot of citrus, sapodilla, mango and guava. Indian Phytopath., 21: 195-197 (1968).

Srivastava, D.N. (1961). Controlling die-back in roses. Indian Horticulture. 5: 24-25.

Vir, D. and Shara, R.K. (1985). Disease of rose and their fungicidal control. Indian Horticulture. 30: 13-15.

\section{How to cite this article:}

Hanwant Kumar, D.S. Patel, Archna Karel and Laxmi Singh. 2018. Testing of pH Range for the Better Growth and Sporulation of B. theobromae. Int.J.Curr.Microbiol.App.Sci. 7(07): 1657-1661. doi: https://doi.org/10.20546/ijcmas.2018.707.194 